\title{
EXPERIMENTAL INVESTIGATION OF THE MICROHARDNESS AND SURFACE ROUGHNESS OF A PRESSURE-DIE-CASTED A413 ALLOY ON MILLING USING THE DESIRABILITY APPROACH
}

\author{
EKSPERIMENTALNA RAZISKAVA MIKROTRDOTE IN \\ POVRŠINSKE HRAPAVOSTI PO REZKANJU TLAČNO LITIH \\ IZDELKOV IZ ZLITINE A413 S PRISTOPOM USTREZNOSTI
}

\author{
Parameswaran Raghunayagan $^{1 *}$, Angamuthu Murugarajan ${ }^{2}$ \\ ${ }^{1}$ Department of Mechanical Engineering, Nehru Institute of Engineering and Technology, Coimbatore, Tamilnadu 641105, India \\ ${ }^{2}$ Department of Mechanical Engineering, Sri Ramakrishna Engineering College, Coimbatore, Tamilnadu 641022, India
}

Prejem rokopisa - received: 2018-10-14; sprejem za objavo - accepted for publication: 2019-01-15

doi:10.17222/mit.2018.223

This research, focused on a newly casted A413 diesel-engine-head aluminium alloy produced under optimal casting conditions by pressure die casting, is also used for a machinability characteristics study. The experiments were methodically conducted based on a central composite face-centred design of the response surface methodology to understand the influence of milling process parameters such as cutting speed ( $\mathrm{m} / \mathrm{min})$, feed rate $(\mathrm{mm} /$ tooth) and depth of cut $(\mathrm{mm})$ on the microhardness (HV) and surface roughness $(\mu \mathrm{m})$. The significance of the responses was validated using the analysis of variance. Multi-objective optimization using the desirability function was adopted to optimize the process parameters that simultaneously maximize the microhardness and minimize the surface roughness. The scanning electron microscopy (SEM) of the machined surface results shows that there is certain surface damage that reduces the quality of final surface components, such as scratches, feed line damage and inclusion of the tool material. Corresponding to the highest desirability, the optimal values of the process parameters were found to be $215.644 \mathrm{~m} / \mathrm{min}$ for the cutting speed, $0.230 \mathrm{~mm} /$ tooth for the feed rate and $1.043 \mathrm{~mm}$ for the depth of cut.

Keywords: microhardness, milling, optimization, prediction, SEM, surface damages

V raziskavi so se avtorji osredotočili na nov dizelski motor iz tlačno lite Al zlitine A413, ki je bil izdelan pri optimalnih pogojih litja. Analizirali so mehansko obdelovalnost tega ulitka. Preizkuse so metodično izvajali na centralni kompozitni strani, da bi razumeli vpliv procesnih parametrov rezkanja, kot so: rezalna hitrost $(\mathrm{m} / \mathrm{min})$, hitrost podajanja $(\mathrm{mm} / \mathrm{zob})$ in globina reza $(\mathrm{mm})$ na mikrotrdoto $(\mathrm{HV})$ in površinsko hrapavost $(\mu \mathrm{m})$. Pomembnost odzivov so ovrednotili z uporabo analize variance. Uporabili so večobjektno optimizacijo z uporabo funkcije ustreznosti za optimizacijo procesnih parametrov, ki istočasno maksimira mikrotrdoto in minimira površinsko hrapavost. Rezkano površino ulitkov so pregledali pod vrstičnim elektronskim mikroskopom (SEM) in našli določene površinske poškodbe, kot so raze in črte ter vključki materiala iz orodja, ki zmanjšujejo kvaliteto površine končnih izdelkov. V skladu s postavljeno najvišjo ustreznostjo so ugotovili, da so optimalne vrednosti procesnih parametrov naslednje: za rezalno hitrost $215,644 \mathrm{~m} / \mathrm{min}, 0,230 \mathrm{~mm} / \mathrm{zob}$ za hitrost podajanja in $1,043 \mathrm{~mm}$ za globino reza.

Ključne besede: mikrotrdota, rezkanje, optimizacija, napoved, SEM, površinske poškodbe

\section{INTRODUCTION}

The achievement of a higher degree of quality in the milled surface is based on the selection of the machining parameters. ${ }^{1}$ In general, several casting components are undergone for the machining operations to achieve a final component. ${ }^{2}$ The objective of the machining operation is to produce a component with quality-based production. In the past few decades, there are several responses observed for understanding the quality of milling operations like surface roughness, vibration amplitude, cutting temperature, tool wear etc. However a small number of research works were focused on machinability along with metallurgical changes in the milling oper-

*Corresponding author's e-mail:

raghunayagan@gmail.com ation. ${ }^{3-5}$ Literature revealed that less significant work studied the relationship between the machining parameters and the surface integrity for aluminium alloys. ${ }^{6,7}$ The material-removal process increases the temperature in the machining region, which causes the combined effects of severe plastic deformation. These deformations affect the machined surface due to metallurgical and physical changes. The metallurgical and physical changes affect the microhardness and surface finish in the milling process. ${ }^{8}$ The strain, temperature and stress are the main sources affecting the micro-hardness during machining processes. However, the strain, temperature and stress can be controlled with an appropriate selection of machining parameters. ${ }^{9}$ Experiments were conducted to study the effects of machining parameters such as cutting speed, feed rate and depth of cut on the surface integrity. The authors observed from the microstructural 
study that the minimum plastic deformation occurred under the milled region. ${ }^{10,11}$ Research work revealed that the cutting parameters show a significant effect on the surface integrity. It has been observed that the microhardness improved due to work-hardening effects and certainly microhardness decreases due to thermal softening effects during the machining process. ${ }^{12}$ Inspected abrasion and adhesion wear on the machined surface via a scanning electron microscope during the milling of aluminium, and also it has been found that re-deposited workpiece material on the machined surface, which reduces the quality of machined components. ${ }^{13}$ SEM micrographs revealed that the appropriate selection of the cutting parameters reduces the surface damage, like deformation feed marks, tearing surface and formation of chip layer on the milled surface. ${ }^{14}$ A higher speed and temperature increased the flow of plastic in the material, which causes deformation feed marks and poor finishing on the machined surface. ${ }^{15}$ The complicated engineering problems can be solved by the formulation of multiobjective optimization techniques. ${ }^{16,17}$ The process parameters optimization in the machining operation has been the subjected to several works using various applications, like Taguchi, GRA, GA, PSO, DF, etc. In this research work, the selection of the method is considered on the desirability function (DF) approach, which allows the optimization with a multi-objective criterion. ${ }^{18-20}$ This approach widely used by several researchers for reasons of its weighting flexibility, simplicity and insertion in statistical software. ${ }^{21,22}$

The present research concentrates on a machinability characteristic study of a newly cast, A413, dieselengine-head aluminium alloy produced under optimal casting conditions by pressure die casting. The interaction effects of the machining parameters such as cutting speed, feed rate and depth of cut on the microhardness and surface roughness were studied using responsesurface methodology. The mathematical models were developed for each response using the analysis-ofvariance technique. The maximum influencing machining parameter was observed with the help of a variance analysis. The desirability approach was adopted for multi-objective optimization and the optimized results were obtained.

\section{PRODUCTION OF A413 ALUMINIUM ALLOY CASTINGS}

The diesel engine heads were fabricated using a horizontal pressure die-casting machine (120T technocrat) under an optimal solution. ${ }^{23}$ The standard short sleeve is coupled with the maximum shot capacity for aluminium of $6.9 \mathrm{~kg}$. A locking force with $400 \mathrm{t}$ capacity inbuilt in the setup and an electric furnace provided with maximum capacity of melting temperature $2000{ }^{\circ} \mathrm{C}$ with 1000 L capacity. The multi-objective optimization tech-

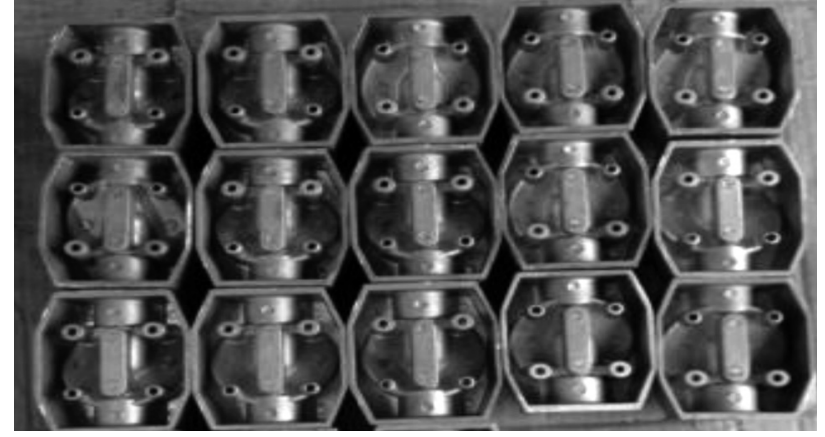

Figure 1: Pressures-die-casted diesel engine head

nique that is the desirability function was adapted to find the optimal parametric solution. Figure 1 shows the pressure-die-casted components under the optimal parametric combinations, such as intensification pressure $20.177 \mathrm{MPa} \cdot \mathrm{Kgf} / \mathrm{cm}^{2}$, shot velocity is $0.4 \mathrm{~m} / \mathrm{s}$ and furnace temperature is $670.348{ }^{\circ} \mathrm{C}$, holding time of $15 \mathrm{~s}$ and retained on the solidifying molten metal for a duration of $60 \mathrm{~s}$ to produce a sound casting. The optical microscope $(\mathrm{OM})$ examinations were carried out following standard metallography techniques using a metallurgical microscope having $500 \times$ magnification. The specimen samples of $(10 \times 10 \times 10) \mathrm{mm}$ were grinded using emery papers of grit size 400, 600, 800, 1200 and 1500, followed by $6-\mu \mathrm{m}$ diamond paste. Further, the polished samples were black-and-white tint etched with Keller's reagent, $95 \mathrm{~mL}$ of distilled water, $2.5 \mathrm{~mL}$ of $\mathrm{HNO}_{3}$, $1.5 \mathrm{~mL}$ of $\mathrm{HCl}$ and $1.0 \mathrm{~mL}$ of $\mathrm{HF}$ used at room temperature and immersed for up to $20 \mathrm{~s}$ or longer to achieve better contrast. The chemical composition of the casted A413 alloy was tested as per ASM and found the presence of alloying elements: $\mathrm{Si}$ 0.4-0.8; Fe $0.7 \mathrm{max} ; \mathrm{Cu}$ 0.5-0.4; Mn 0.15 max; Mg 0.8-1.2; Cr 0.04-0.35 max; Zn 0.25 max; Ti 0.15 max , Al - balance.

The pressure-die-casted samples were tested as per the American Society for Testing and Materials (ASTM) standard procedures and found that the microhardness of the cast samples improved by about $10 \%$ to $25 \%$ compared to the gravity die-casting method. ${ }^{24}$ The maximum microhardness achieved under optimal parametric combination is $119.535 \mathrm{HV}$.

\section{EXPERIMENTAL PART}

\subsection{Experimental setup and design}

The experiment was conducted using MAKE-BROTHER S700X1 CNC vertical machining centre (MCVMC) to conduct the face milling operation on the cast A413 diesel-engine-head aluminium alloy using the HSS tool. The process-parameter ranges are shown in Table 1, and were selected based on preliminary research work. ${ }^{19}$ 
Table 1: Milling process parameters

\begin{tabular}{|c|c|c|c|c|}
\hline \multirow{2}{*}{$\begin{array}{c}\text { Process } \\
\text { parameters }\end{array}$} & \multirow{2}{*}{ Units } & \multicolumn{3}{|c|}{ levels } \\
\cline { 3 - 5 } & & -1 & 0 & 1 \\
\hline $\mathrm{A}$ & $\mathrm{m} / \mathrm{min}$ & 111 & 166.5 & 222 \\
\hline $\mathrm{B}$ & $\mathrm{mm} / \mathrm{tooth}$ & 0.08 & 0.16 & 0.24 \\
\hline $\mathrm{C}$ & $\mathrm{mm}$ & 0.5 & 1 & 1.5 \\
\hline
\end{tabular}

Table 2: Milling process parameters

\begin{tabular}{|c|c|c|c|c|}
\hline $\begin{array}{c}\mathrm{A} / \\
\mathrm{m} / \mathrm{min}\end{array}$ & $\begin{array}{c}\mathrm{B} / \\
\mathrm{mm} / \text { tooth }\end{array}$ & $\begin{array}{c}\mathrm{C} / \\
\mathrm{mm}\end{array}$ & $\begin{array}{c}\mathrm{MH} / \\
\mathrm{HV}_{500}\end{array}$ & $\begin{array}{c}R_{\mathrm{a}} / \\
\mu \mathrm{m}\end{array}$ \\
\hline 222 & 0.16 & 1 & 129.1 & 0.73 \\
\hline 111 & 0.24 & 1.5 & 133.1 & 1.1 \\
\hline 111 & 0.08 & 0.5 & 127.8 & 0.86 \\
\hline 166.5 & 0.16 & 1 & 130.1 & 0.87 \\
\hline 166.5 & 0.16 & 0.5 & 123.5 & 0.81 \\
\hline 111 & 0.16 & 1 & 130.8 & 1.08 \\
\hline 222 & 0.08 & 1.5 & 119.7 & 0.72 \\
\hline 166.5 & 0.24 & 1 & 130.2 & 0.81 \\
\hline 222 & 0.24 & 0.5 & 127.6 & 0.73 \\
\hline 166.5 & 0.16 & 1 & 131.2 & 0.89 \\
\hline 166.5 & 0.16 & 1.5 & 127.9 & 0.92 \\
\hline 166.5 & 0.16 & 1 & 129.2 & 0.93 \\
\hline 166.5 & 0.16 & 1 & 128.9 & 0.95 \\
\hline 166.5 & 0.16 & 1 & 128.6 & 0.94 \\
\hline 166.5 & 0.08 & 1 & 125.1 & 0.81 \\
\hline
\end{tabular}

Fifteen sets of experiments were conducted for the microhardness and surface roughness with central composite face centred $(\mathrm{CCF})$ design of the response surface methodology. The face milled diesel engine head is depicted in Figure 2.

Further, using a Vickers microhardness tester, the microhardness of the machined surface was measured by applying a load of $0.4903325 \mathrm{~N}$ with a time interval of $5 \mathrm{~s}$. The average microhardness is recorded by repeating the experiment three times and is tabulated in Table 2. The experimental setup of the microhardness tester is shown in Figure 3.

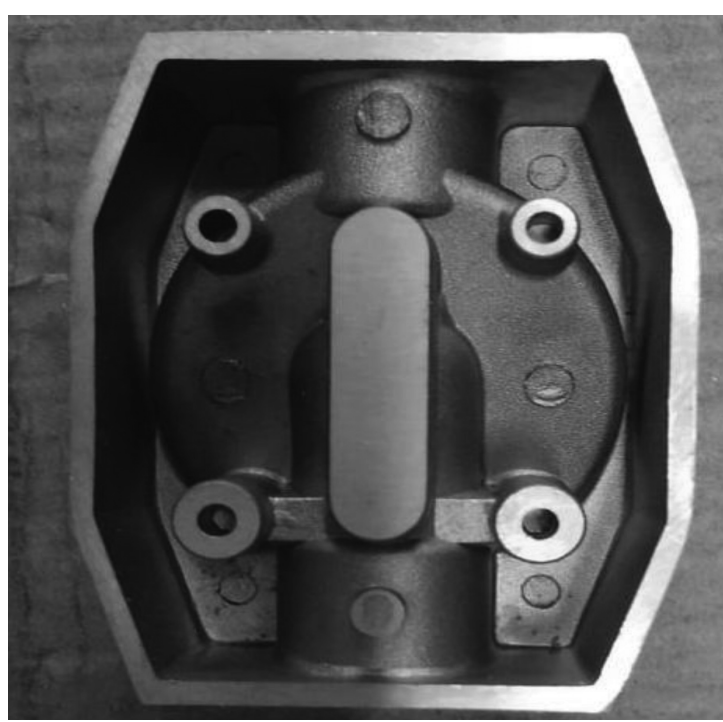

Figure 2: Face-milled diesel engine head

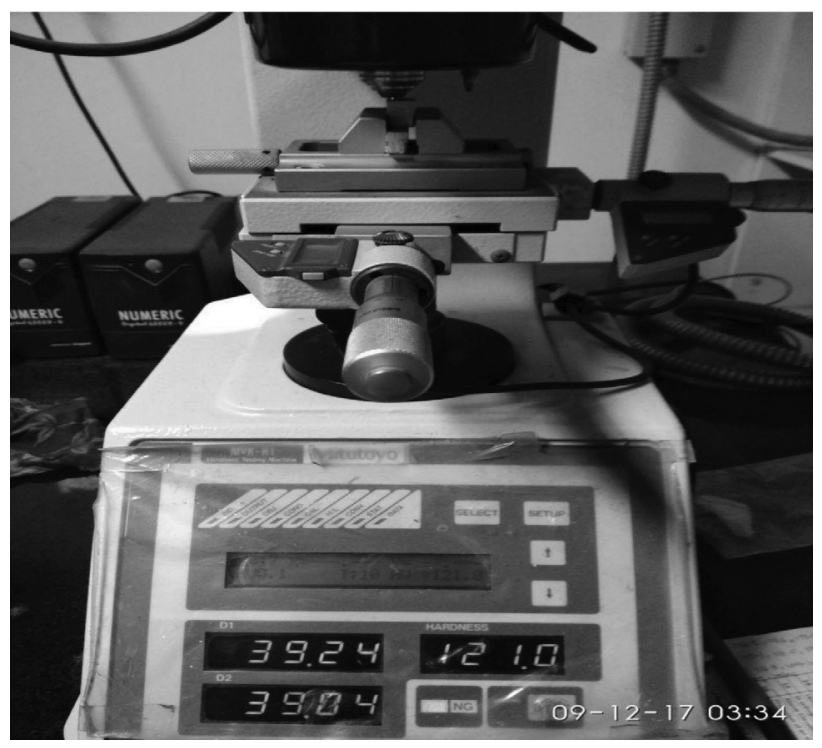

Figure 3: MITUTOYO microhardness tester

The XY stage of the tester offers a load ranging from $10 \mathrm{~g}$ to $1 \mathrm{~kg}$ with magnifications of $100 \times$ and $400 \times$. The surface roughness on the machined surface was measured at three different positions with a surf tester device, model SJ - 210 and the average value of the surface roughness is noted in microns and tabulated in Table 2.

\section{RESULTS AND DISCUSSION}

\subsection{Statistical analysis}

The F-statistical value of the feed rate $\mathrm{B}(8.63)$ influences more on the microhardness by comparing the values of the cutting speed $\mathrm{A}(0.958) \mathrm{m} / \mathrm{min}$, and the depth of cut $\mathrm{C}(6.423) \mathrm{mm}$. The F-statistical value of depth of cut $\mathrm{C}(1)$ influences more on the surface roughness when compared to the other parameters, like cutting speed $\mathrm{A}(34.02) \mathrm{m} / \mathrm{min}$, feed rate $\mathrm{B}(0.005) \mathrm{mm} /$ tooth. The $R^{2}$ value (0.95), (0.95) and predicted $R^{2}$ value ( -4.1 ), $(-3.22)$ of both the surface roughness and the microhardness shows the closeness in the data fitted in the regression line.

Equation (1) and (2) portrayed the advanced regression models:

$\mathrm{HV}=+142.16078431373-0.23566507684155$

$* \mathrm{~A}-100.03676470588 * \mathrm{~B}+2.294117647059$

$* \mathrm{C}+0.67567567567568 * \mathrm{~A} * \mathrm{~B}-0.0324 * \mathrm{~A} * \mathrm{C}+$

$67.499999999999 * \mathrm{~B} * \mathrm{C}+0.00043445671426594 * \mathrm{~A} * \mathrm{~A}-1$

$50.27573529412 * \mathrm{~B} * \mathrm{~B}-11.64706 * \mathrm{C} * \mathrm{C}$

$R \mathrm{a}=+0.63460784313725-0.0036 * \mathrm{~A}+$ $4.7371323529412 * \mathrm{~B}+0.78794117647059 * \mathrm{C}-0.0005630$ $6306306299 * \mathrm{~A} * \mathrm{~B}-0.002252 * \mathrm{~A} * \mathrm{C}-1.1875 * \mathrm{~B} * \mathrm{C}+$ $0.00000840267 * \mathrm{~A} * \mathrm{~A}-10.799632352941 * \mathrm{~B} * \mathrm{~B}-0.056470$ $588 * \mathrm{C} * \mathrm{C}$ 

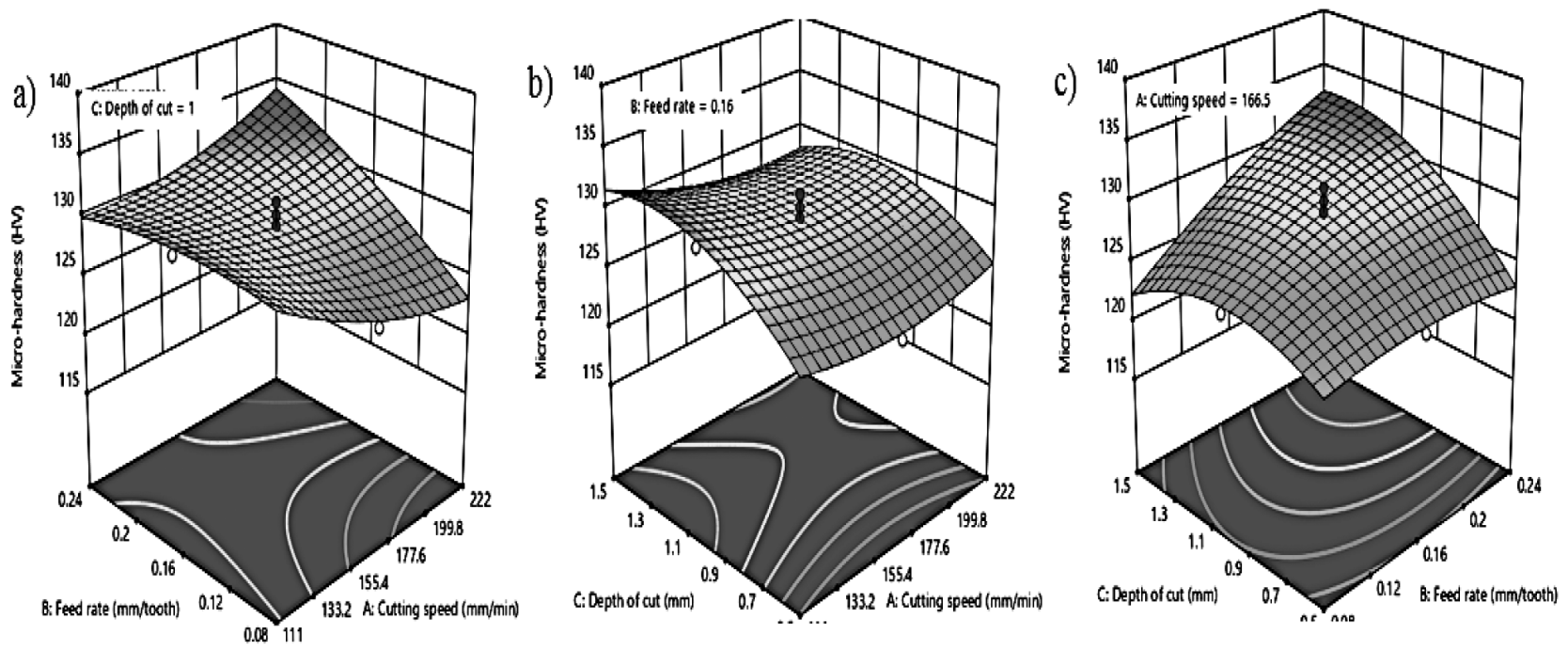

Figure 4: Interaction effects of the process parameters on the microhardness

\subsection{Response Surface Methodology (RSM)}

\subsubsection{Interactive effect of process parameters on micro- hardness}

Figures $4 \mathbf{a}$ to $\mathbf{4 c}$ depict the interaction effect of the process parameters on the microhardness, which shows a significant effect on the microhardness. The micro hardness directly influences the feed rate and has an inverse relationship with the cutting speed, i.e., increase in feed rate increases the microhardness and a better microhardness can be obtained at a lower cutting speed. The microhardness (125 $\mathrm{HV}$ to $133 \mathrm{HV}$ ) of the machined surface is improved for the range of the feed rate from $0.08 \mathrm{~mm} /$ tooth to $0.10 \mathrm{~mm} /$ tooth with a lower cutting speed. When the cutting speed increases, the depth of cut shows a parabolic trend with decreases in the microhardness, which is portrayed in Figure $\mathbf{4 b}$, the combined effect of depth of cut and cutting speed. This is due to the reason, the thermal softening effect of the material.

For the optimal range of depth of cut between 0.75 $\mathrm{mm}$ and $1 \mathrm{~mm}$ the microhardness is increased relatively, lowering the cutting speed. When the feed rate decreases the depth of cut depicts a parabolic trend of microhardness in Figure 4c. The maximum microhardness is achieved between the optimal range of $0.75 \mathrm{~mm}$ and $1 \mathrm{~mm}$ of depth of cut and higher feed rate.

\subsubsection{Microstructural analysis}

Figures $\mathbf{5 a}$ and $\mathbf{5 b}$ show the microstructure of the base metal and the machined metal for (Trial no. 2). A value of $41 \mu \mathrm{m}$ was found to be the average grain size for the base metal using mean linear intercept method. The grain size were more elongated and gradually decreased after machining, as severe plastic deformation was induced. A Vickers microhardness tester was adopted to measure the microhardness of the machined surface by applying a load of $50 \mathrm{gf}$ with a time interval of $5 \mathrm{~s}$. From the result, the microhardness of the machined surface was found to be greater compared to the base metal (119.5 HV). Between the ranges of $119.7 \mathrm{HV}$ to 133.1 $\mathrm{HV}$ the microhardness was measured across the crosssection of the machined samples. This increase in value shows the predominant effect of strain hardening during the machining process.

\subsubsection{Interactive effect of process parameters on the surface roughness}

It is observed from Figures $\mathbf{6 a}$ to $\mathbf{6} \mathbf{c}$ that the process parameters have significant effects on the responses. Figure 6a depicts that the surface roughness is inversely
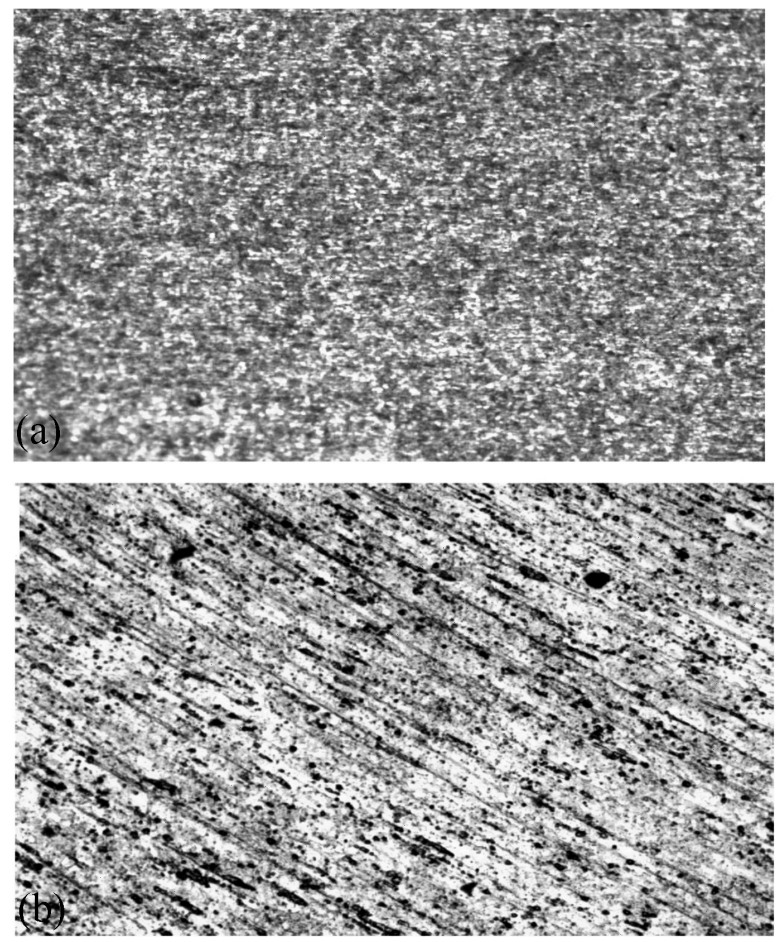

Figures 5: Microstructure of engine head: a) base metal, b) machined sample 

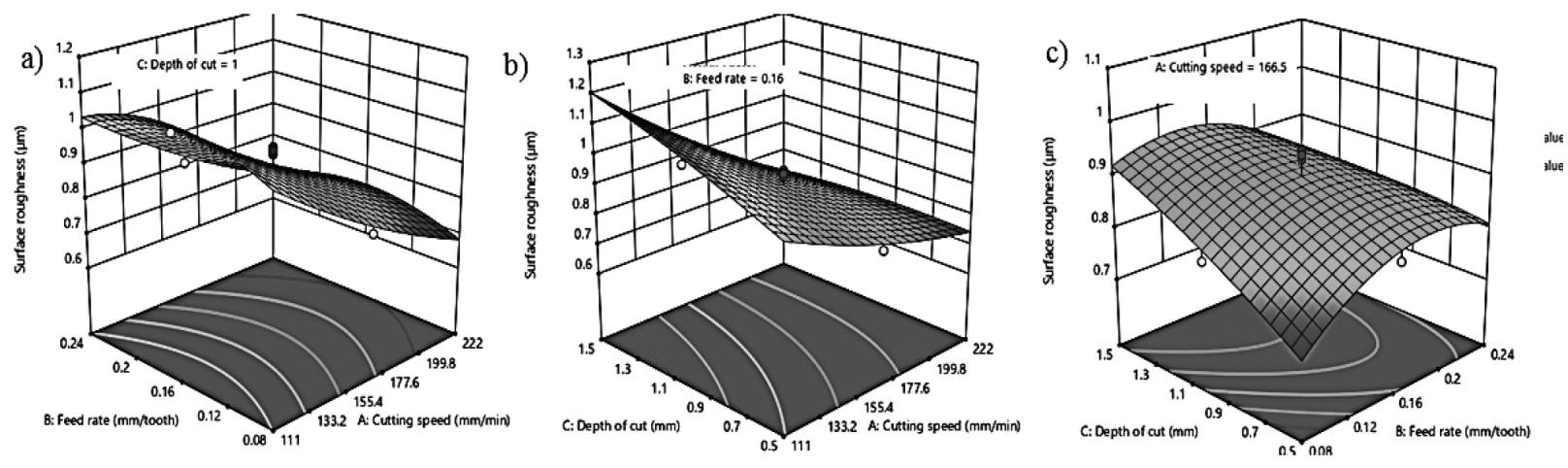

Figures 6: Interaction effects of process parameters on the microhardness

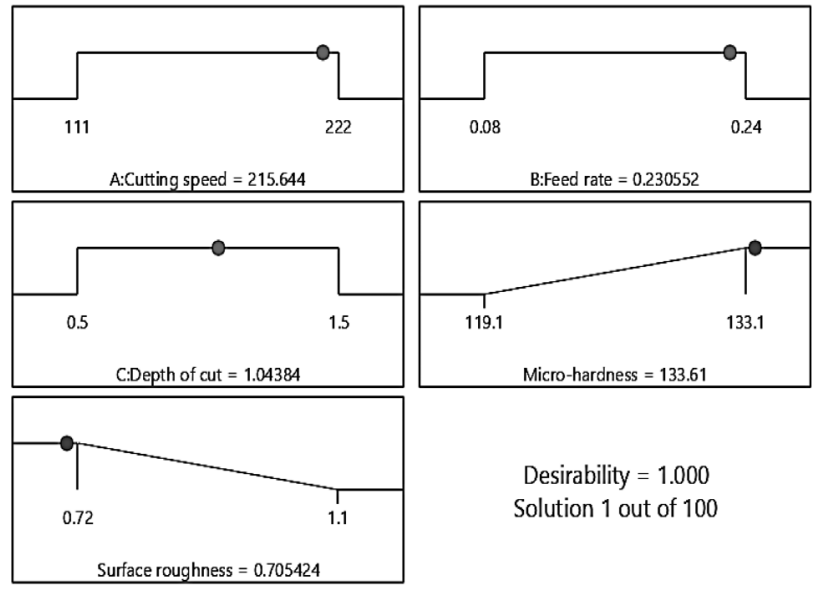

Figure 7: Ramp functions of process parameters and responses

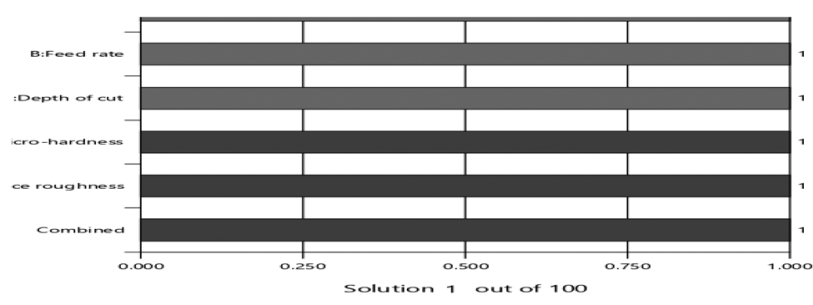

Figure 8: Bar graph of the process desirability function proportional to the cutting speed and the better surface roughness is obtained between $210 \mathrm{~m} / \mathrm{min}$ to $222 \mathrm{~m} / \mathrm{min}$. For higher cutting speed, the feed rate pf $0.08 \mathrm{~mm} /$ tooth to $0.12 \mathrm{~mm} /$ tooth reduces the surface roughness $(0$. $93 \mu \mathrm{m}$ to $0.72 \mu \mathrm{m})$. Figure $\mathbf{6 c}$ depicts that the depth of cut is inversely proportional to the cutting speed. Surface roughness is directly proportional to the depth of cut, as a higher depth of cut increases the cutting force, which in turn makes the tool and workpiece unstable, resulting in an increased surface roughness. At a higher cutting speed the depth of cut of $0.5-0.8 \mathrm{~mm}$ does not show a significant effect, but a large amount of torque is produced for the lower cutting speed. There is a gradual increase in the depth of cut from $1 \mathrm{~mm}$ to $1.5 \mathrm{~mm}$ for the cutting speed of $111 \mathrm{~m} / \mathrm{min}$ to $150 \mathrm{~m} / \mathrm{min}$, which proportionally increases as the surface roughness increases. Henceforth, it is concluded that the quality of the surface finish is obtained at a higher cutting speed and a lower depth of cut.

\subsubsection{Multi-objective optimization}

The objective of the optimization for the face milling of the pressure-die-casted engine head provides the optimum process parameters for the minimum surface roughness and the maximum microhardness. The mechanical property of the component is enhanced with a
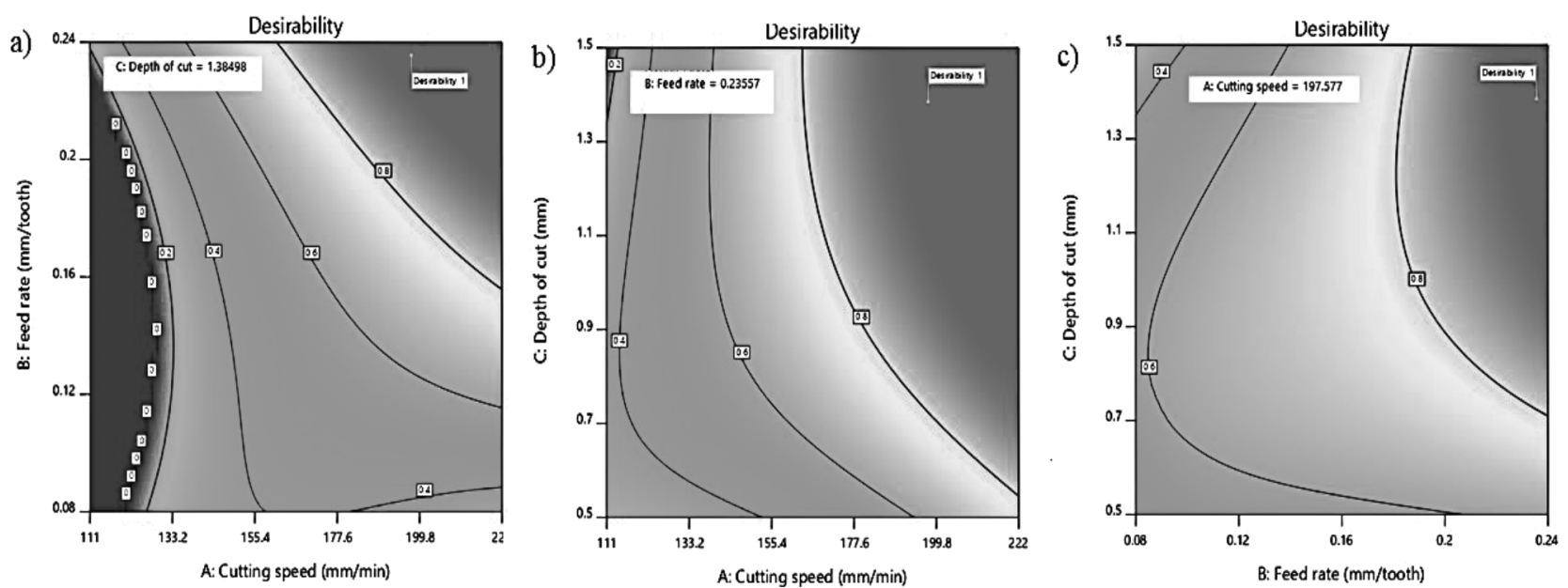

Figures 9: Contour plots for the overall desirability 
better quality finish by the optimum process parameter. By comparing the responses, the desirability values close to 1 unit were taken as the most effective parameter value. Figure 7 depicts the ramp functions. The optimal values of the process parameters are found to be 215.644 $\mathrm{m} / \mathrm{min}$ for the cutting speed, $0.230 \mathrm{~mm} /$ tooth for the feed rate, and $1.043 \mathrm{~mm}$ for the depth of cut from Figures 7 and 8. Figures 9a to 9c depict that the output response achieved $100 \%$ desirability and Figure 8 depicts the overall desirability function of the responses. The bar
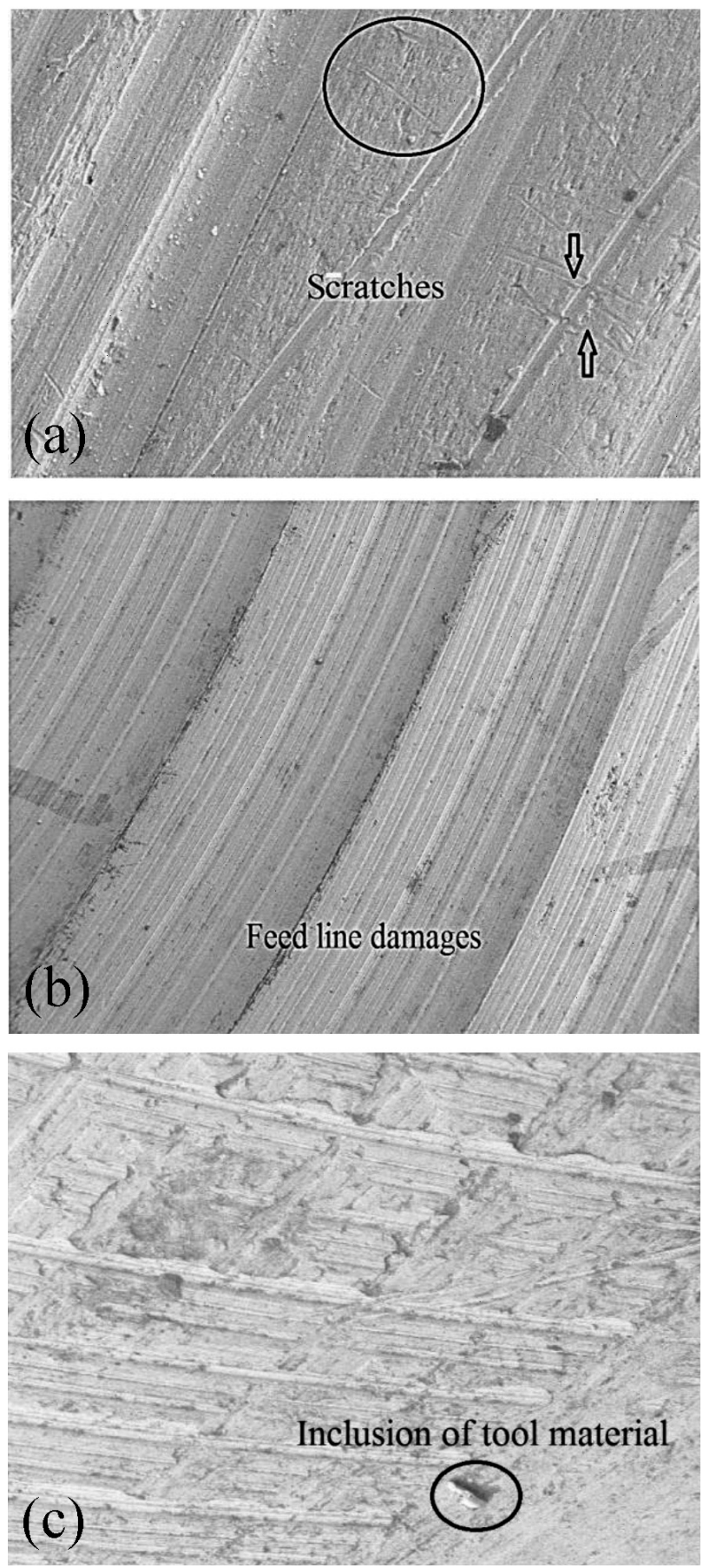

Figures 10: Surface damages graph depicts the satisfaction of each variable for the criterion and a value close to one is considered proficient. ${ }^{24}$ Figures 9a to 9c show that the right-hand side shows the optimal region with a desirability value of 1 , which is gradually reduced when moved towards the downward and the left-hand side. Corresponding to highest desirability, the optimal combination of the face milling parameters for multi-performance maximizes the microhardness at about $133.61 \mathrm{HV}$ and minimizes the surface roughness at about $0.705 \mu \mathrm{m}$. The predicted optimal values verified with the experimental values obtained corresponding to the optimal setting for the microhardness of 134.89 and the surface roughness of about $0.685 \mu \mathrm{m}$ that are closer to the predicted values. The error percentage observed from the experimental versus the predicted falls with less than $3.7 \%$.

\subsubsection{Analysis of the machined surface using an SEM}

Figures 10a to 10c portray the results of the surface damage, including scratches, feed line damage, and inclusion of the tool. It is known that in the turning operation where tool is continuously having contact with the workpiece, but in milling, the machining operation is focused to be intermittent, wherein the milling cutter engages and disengages, alternatively, with the workpiece. $^{23}$

Also, sudden engagement with the lower cutting speed, which gives chances of more contact between the work-tool interfaces, causes scratches on the workpiece shown in Figure 10a, so applying a higher cutting speed will enhance the quality of the final component. Above the nominal feed rate value, it produced aggressive feed marks, shown in Figure 10b. From the observation of Figure 10c, a sudden disengagement of the tool causes the inclusion of the tool material, which was welded on the workpiece during the cutting to be torn off, keeping some of the tool material with itself.

\section{CONCLUSIONS}

The experiments were performed based on the CCF design on a newly cast, A413, diesel-engine-head, aluminium alloy, produced under optimal casting conditions by pressure die casting, to measure the microhardness and the surface roughness. Design Expert version 11 was used for the statistical analysis. The desirability function analysis was adopted to optimize the process parameters that simultaneously maximize the microhardness and minimize the surface roughness. The effects of the machining parameters for the responses rate were analysed using the analysis of variance. The following conclusions are drawn from the multi-objective optimization and the SEM analysis.

Comparing all the other parameters, the F-statistical value is recognized to be of feed rate, which has a better influence on the microhardness. The values of the cutting speed $\mathrm{A}(0.958)$, the feed rate $\mathrm{B}(8.63)$ and the depth of 
cut $\mathrm{C}(6.423)$. The cutting speed $\mathrm{A}(34.02)$, the feed rate $\mathrm{B}(0.005)$ and the depth of cut $\mathrm{C}(1)$ carry out an indication that the F-statistical value, which is the depth of cut, has a great influence on the surface roughness, compared to all the other parameters.

It was found that for all the cases, the microhardness of the machined surface was higher than the base metal (119.5 HV). The micro-hardness measured across the cross-section of the samples was in the range from 119.7 $\mathrm{HV}$ to $133.1 \mathrm{HV}$. The increase in the microhardness of the machined surface is attributed to the predominant effect of the strain hardening or the work hardening during the machining process.

The observation from the SEM analysis on machined surface results is surface damage, including scratches, feed line damage, and inclusion of the tool. Sudden engagement with the lower cutting speed, which gives chances of more contact between the work-tool interfaces, causes scratches on the work piece.

Corresponding to the highest desirability, the optimal combination of face-milling parameters for multi-performance maximizes the micro-hardness at about 133.61 $\mathrm{HV}$ and minimizes the surface roughness at about $0.705 \mu \mathrm{m}$. The predicted optimal values verified with the experimental values obtained corresponding to optimal setting for microhardness $134.89 \mathrm{HV}$ and surface roughness about $0.685 \mu \mathrm{m}$ that are closer to the predicted values.

The results achieved in this study can be applied in various applications for further study.

\section{REFERENCES}

${ }^{1}$ G. Mahesh, S. Muthu, S. R. Devadasan, Prediction of surface roughness of end milling operation using genetic algorithm, The International Journal of Advanced Manufacturing Technology, 77 (2015) 1-4, 369-381

${ }^{2}$ P. Senthil, S. Vinodh, A. K. Singh, Parametric optimisation of EDM on Al-Cu/TiB2 in-situ metal matrix composites using TOPSIS method, International Journal of Machining and Machinability of Materials, 16 (2014) 1, 80-94

${ }^{3}$ M. S. Uddin, H. Rosman, C. Hall, P. Murphy, Enhancing the corrosion resistance of biodegradable $\mathrm{Mg}$-based alloy by machininginduced surface integrity: influence of machining parameters on surface roughness and hardness, The International Journal of Advanced Manufacturing Technology, 90 (2017), 5-8, 2095-2108

${ }^{4}$ F. Wang, J. Zhao, A. Li, J. Zhao, Experimental study on cutting forces and surface integrity in high-speed side milling of Ti-6Al-4V titanium alloy, Machining Science and Technology, 18 (2014), 3, 448-463

${ }^{5}$ Y. Zedan, V. Songmene, R. Khettabi, J. Kouam, J. Masounave, Surface integrity of Al6061-T6 drilled in wet, semi-wet and dry conditions, Proc. of the $37^{\text {th }}$ International MATADOR Conference, Manchester, 2012, 131-134

${ }^{6}$ A. A. Zouhayar, B. M. Naoufel, Y. Houda, S. Habib, Surface integrity after orthogonal cutting of aeronautical aluminum alloy 7075-T651, Design and modeling of mechanical systems, Springer, Berlin, Heidelberg 2013, 485-492

${ }^{7}$ A. Ginting, M. Nouari, Surface integrity of dry machined titanium alloys, International Journal of Machine Tools and Manufacture, 49 (2009) 3, 325-332
${ }^{8}$ A. H. Musfirah, J. A. Ghani, C. C. Haron, Tool wear and surface integrity of inconel 718 in dry and cryogenic coolant at high cutting speed, Wear, 376 (2017) 125-133

${ }^{9}$ M. Salahshoor, Y. B. Guo, Surface integrity of biodegradable orthopedic magnesium-calcium alloy processed by high speed machining, Medical Device Materials VI: Proc. from the Materials and Processes for Medical Devices Conference: (MPMD 2011), ASM International, 2013, 125

${ }^{10}$ R. S. Pawade, S. S. Joshi, P. K. Brahmankar, Effect of machining parameters and cutting edge geometry on surface integrity of highspeed turned Inconel 718, International Journal of Machine Tools and Manufacture, 48 (2008) 1, 15-28

${ }^{11}$ B. Singaravel, T. Selvaraj, Optimization of machining parameters in turning operation using combined TOPSIS and AHP method, Tehnicki vjesnik-Technical Gazette, 22 (2015) 6, 1475-1481

${ }^{12}$ F. Wang, J. Zhao, A. Li, J. Zhao, Experimental study on cutting forces and surface integrity in high-speed side milling of Ti-6Al-4V titanium alloy, Machining Science and Technology, 18 (2014) 3, 448-463

${ }^{13}$ S. Ramesh, L. Karunamoorthy, K. Palanikumar, Surface roughness analysis in machining of titanium alloy, Materials and Manufacturing Processes, 23 (2008) 2, 174-181

${ }^{14}$ N. Masmiati, A. A. Sarhan, Optimizing cutting parameters in inclined end milling for minimum surface residual stress - Taguchi approach, Measurement, 60 (2015) 267-275

${ }^{15}$ J. Chen, Q. Fang, P. Li, Effect of grinding wheel spindle vibration on surface roughness and subsurface damage in brittle material grinding, International Journal of Machine Tools and Manufacture, 91 (2015) 12-23

${ }^{16}$ A. Konak, D. W. Coit, A. E. Smith, Multi-objective optimization using genetic algorithms: A tutorial, Reliability Engineering \& System Safety, 91 (2016) 9, 992-1007

${ }^{17}$ U. Umer, J. A. Qudeiri, H. A. M. Hussein, A. A. Khan, A. R. AlAhmari, Multi-objective optimization of oblique turning operations using finite element model and genetic algorithm, The International Journal of Advanced Manufacturing Technology, 71 (2014) 1-4, 593-603

${ }^{18}$ V. Kumar, V. Kumar, K. K Jangra, An experimental analysis and optimization of machining rate and surface characteristics in WEDM of Monel-400 using RSM and desirability approach, Journal of Industrial Engineering International, 11 (2015) 3, 297-307

${ }^{19}$ A. A. Selaimia, M. A. Yallese, H. Bensouilah, I. Meddour, R. Khattabi, T. Mabrouki, Modeling and optimization in dry face milling of X2CrNi18-9 austenitic stainless steel using RMS and desirability approach, Measurement, 107 (2017), 53-67

${ }^{20}$ A. Chabbi, M. A. Yallese, I. Meddour, M. Nouioua, T. Mabrouki, F. Girardin, Predictive modeling and multi-response optimization of technological parameters in turning of Polyoxymethylene polymer (POM C) using RSM and desirability function, Measurement, 95 (2017) 99-115

${ }^{21}$ K. Tank, N. Shetty, G. Panchal, A. Tukrel, A., Optimization of turning parameters for the finest surface roughness characteristics using desirability function analysis coupled with fuzzy methodology and ANOVA, Materials Today: Proc., 5 (2018) 5, 13015-13024

${ }^{22}$ A. Murugarajan, P. Raghunayagan, The impact of pressure die casting process parameters on mechanical properties and its defects of A413 aluminium alloy, Metalurgija 58 (2019) 1-2, 55-58

${ }^{23}$ S. Zahoor, N. A. Mufti, M. Q. Saleem, M. P. Mughal, M. A. M. Qureshi, Effect of machine tool's spindle forced vibrations on surface roughness, dimensional accuracy, and tool wear in vertical milling of AISI P20, The International Journal of Advanced Manufacturing Technology, 89 (2017) 9-12, 3671-3679

${ }^{24}$ N. Zeelanbasha, V. Senthil, B. Sharon Sylvester, N. Balamurugan, Modeling and experimental investigation of LM26 pressure die cast process parameters using multi objective genetic algorithm (moga), metabk, 56 (2017) 3-4, 307-310 